\title{
Communication of Violence, Religious Culture and Nationalism in $A$ Bend in the Ganges
}

\author{
Udaya Raj Paudel \\ Doctoral Candidate in English (Communication), Tribhuvan University, Kathmandu, Nepal \\ udayapaudel7@gmail.com
}

Published Date: September 01, 2018

Abstract: This paper tries to analyze $A$ Bend in the Ganges by Manohar Malgonkar in terms of Gyanendra Pandey's critique of partition historiography and nationalism, and V. D. Savarkar's ideology of Hindutva or Hindu Rastra. Although both views are critical of the attempts by traditional historiographers to erase the violent history of India, their critiques of traditional historiography have diametrically opposite purposes and interests to serve. Pandey writes from a Marxist subaltarnist point of view, emphasizing the oppression of minorities like women, dalits, and Muslims at the hand of the state which he sees as predominantly serving the interests of upper class Hindus, whereas Savarkar and Malgonkar emphasize the need for a strong nation and people based on common religious and cultural aspirations. The ideology of Hindutva as formulated by Savarkar which sees religion as the most important element in deciding the loyalty of the people and sees violence as an effective tool against tyranny is amply reflected in the novel by Malgonakar. Savarkar and Malgonkar moreover see non-violence of the kind envisioned by Gandhi as being too idealistic and hence incompatible in the everyday world where the very existence sometimes depends on the effective use of violence.

\section{CONCEPTUAL AND CONTEXTUAL BACKGROUNDS}

The violence of partition changed the social and political course of the Indian subcontinent in such a way that its ramifications are still palpable. Along with the number of death and the amount of destruction, the event left a deep psychological scar on the mind of millions of people in general and on the mind of women and children in particular. It was definitely the first of its kind in the modern history of human civilization that people would forget and forgo all kinds of bonds between them in the name of religion. Perhaps overshadowed by the immediately preceding catastrophe of the II World War and to some extent by the relatively insignificant political weight of the continent itself, the violence of partition was never a subject of serious academic and political consideration. While the violence perpetrated during the II World War particularly against the Jews by the Nazi Germany is still a subject of significant research and debate, the interest in the violence of partition is relatively a recent subject matter coinciding with the economic rise of India and its subsequent political clout.

The central attempt of this research paper hence is to see the relation between violence, religion, and nationalism in the world in general and in the Indian subcontinent in particular. The researcher attempts at seeing the force of religion in determining the world views and national loyalties. The subcontinent serves as a perfect site to examine the effect of religion since a separate country had to be created due to religious differences. Moreover the paper tries to analyze the effect of history on the present by focusing on the troubled history of India. The Indian subcontinent has gained immensely in terms of cultural, political, and religious heritages resulting from the invasions. But as Savarkar is quick to point out the price paid by the Indian people in their blood and flesh has made those interactions real nightmares. Those interactions especially with the Muslims have heavily changed the political and cultural landscape of the continent and still threaten to do so. The paper moreover tries to explicate the effect of partition on the Muslim minority in India who are sometimes subjected to severe psychological strain given the earlier demand for a Muslim nation. The flawed nature of partition and its effect 
will be dealt in some length in this paper. Moreover, the paper looks into the implication of the issues raised by the ideology of Hindutva that sees India as a country with two nations and demands for the restructuring of national ideals on the basis of religion and culture. By rejecting territorial nationalism in favor of cultural nationalism, the paper contends that the ideology of Hindutva tacitly denies the stake of Muslims in India. This ideology will be compared and contrasted with the Gandhian principles to see the effectiveness of violence in determining the course of history.

While deserving praise for foregrounding the struggles of minority and violence during partition, Pandey's critique of historiography, however, slides rather ironically into a critique of Hindu nationalism, and uncritically assumes a parochial view of Muslims as victims and Hindus as perpetrator. Focusing too much on Muslim minority in India, Pandey fails to see the persecution of Hindus in countries like Pakistan and Bangladesh where unlike in India the minority communities are stripped off their basic constitutional and human rights. A Bend in the Ganges however tries to capture this age-old tension between Hindus and Muslims from a civilizational point of view by making the historical incidents bear upon the consciousness of the present. Despite engaging in what Fredric Jameson calls "politics of blame" (qtd. in Niranjana 166), thereby blaming largely Gandhi and Congress for partition, the novel nonetheless brings forth the wide chasm between two different world views and raises several questions, in line with the ideology of Hindutva, regarding the rationale behind partition and the continuous presence of Muslims in India. Although Savarkar and Malgonkar outrightly reject the partition of India on the basis of religion, their support for what has come to be known as cultural nationalism fails to show how two different people who constitute two nations could unite in a single country.

Beginning with the late twentieth century, the world has witnessed a continual rise in religious sentiments around the world as part of identity politics. With the fall of Soviet Union, according to Samuel P. Huntington, "The most important distinctions among peoples are not ideological, political, or economic. They are cultural." And "the most dangerous conflicts are those along the fault lines between civilizations" (21-28). The Indian subcontinent as a center of two major civilizations hence provides a space to look into the nature of the undergoing clash between two civilizations. In fact, the clash envisioned by Huntington took place some sixty years ago when a separate land was created given the inability of two religions to live together. Although it has become customary to label any religiously motivated struggles as fanaticism, a term designed and despised by western liberal democracy, contemporary turmoil in Iraq, Lebanon, Sri Lanka, Afghanistan, and Kashmir provide a vivid picture of a religion's inherent capability in motivating people and their struggles. All these struggles have their direct root in religion with a somewhat exception being the Tamil issue in Sri Lanka which is thought to be an ethnic struggle with its religious motivations somewhat blurred and undetermined. What more, unlike ideological struggles that have been found to be relatively easier to adjust and compromise with as witnessed in Nepal, religious and cultural differences extend quite considerably and are much more difficult to deal with.

In the struggles between different civilizations, like in any other kind of struggles, violence has been one of the central and salient features. The degrees of acceptability of violence, its usefulness, and the religious or political sanctions of violence have been a subject of intense dispute. Moderate voices in any religion or culture generally term their religion as essentially non-violent. Hinduism, Christianity, or Islam, for instance, are said to preach peaceful coexistence. But in my view, what a religion indeed says or sanctions is secondary to the political and ideological use of religion and that scriptures like any other texts can be interpreted according to one's conviction and convenience. Focusing on the representation of violence in the mainstream history, the present study also analyzes the politics behind the valorization and demonization of violence in national historiography. According to Gyanendra Pandey, "Indian historians have drawn an important dividing line between the history of nationalism in India leading to independence in 1947, and the history of what is called 'communalism' leading to the partition" (Remembering 12). 
While a work on partition historiography with a whole lot of claims and counterclaims and an enormous body of writing can never be complete in itself and do justice to the victims, the work by being selective rather than exhaustive, makes a modest attempt at understanding the hierarchy of violence, its simultaneous rejection and glorification by traditional historiography, its employment in presenting a unified self, and politics behind its representation. A theoretical critique of partition historiography then becomes necessary to understand the representation of violence and the construction of nationalism.

\section{A Theoritical Debate: Representation of Violence in Partition Historiography}

Revisionist historiography of postmodern bent criticize the traditional idealist historiography that represents a society in a normalized and homogenized way, with all its social texture smoothed, its local specificity subordinated and its documentary evidence submerged by paraphrase for the sake of a coherent narratable plot. "Historian's history" of the partition of India and Pakistan, influenced by colonialist historiography, never falls in an exceptional category that can represent violent events and sufferings in their fullness. Even after the independence, it is filled with a double bind where historians repudiate the colonizer's construction of Indian people and India and yet follow the colonialist model of history. Pandey contends: "Although Indian historians have long since moved away from this rather convoluted celebration of the benefits of British rule, they seem to have remained tethered to certain basic tenets of the colonialist narrative on history, violence and civilization"(Remembering 58). Therefore, academic histories of the subcontinent remain mimicry of European historiography that discourages representation of violence, heterogeneity of a society and the painful stories of individuals in the name of rationality, progress and objectivity. Histories of both India and Pakistan hide the religiously motivated upheavals of 1947 as irretrievably "other" in relation to the organs of political rationality and progress. Since no community or individual would like to represent itself as violent and hence uncivilized, official histories shy away from a frank discussion of the "history of rape, abduction and killing, and the state sponsored drive that followed to evict aliens and recover nationals, irrespective of their wishes, which disturbingly capture the meaning of partition" "Voices" 234). The extreme apathy towards thousands killed is grotesquely visible when both India and Pakistan commemorate their independence and martyrs where seldom is a word addressed to those perished in the bloodlust. Reasons behind obliterating violence are various. However, the professed motive is to secure the peaceful coexistence of "different peoples."

Attempts to erase violence from history and by extension memory directly emanates from the centrality of state in the project of writing history. According to Hegel, State, the main controlling agent of violent people, assures civilization. At the same time "state equates history" (qtd. in Remembering 54). In the hierarchy of violence, only the violence perpetrated by state, which is rational and purposeful, is deemed worthy of consideration. Javeed Alam, an Indian Marxist and political scientist, and Suresh Sharma distinguish three kinds of violence. The first kind refers to the violence organized and perpetrated by the state as in the Holocaust or as witnessed in Bosnia and Croatia. The second kind relates to the involvement of large scale organizations like the one witnessed in anti-Sikh riots after the assassination of the then prime minister Indira Gandhi by her Sikh bodyguards in 1984 and the anti-Muslim riots of 1992-1993 over Babri Mashjid issue. This type of violence becomes possible where state becomes a silent spectator to those events. The third kind relates to the violence in its raw and unorganized form where people become victims of violence at a moment of loss of sanity and suspension of judgment ("Partition" 101). This is the violence witnessed in partition and should be forgotten in the best interest of the social harmony and normal everyday life. Any mention, let alone institutionalization of it, is detrimental to the project of nationalism, progress and rationality. Detailed representation of violence and its analysis has never been a subject of honest and frank analysis since it is an ongoing and ever present threat in present-day India. Indian historiography makes every attempt to obliterate the violence so as to preserve what is singularly unique about India, its "unity in diversity." (60)

The attempt here again is to erase the violence out of memory and out of history in the best interest of all. However, the intense harping on "unity in diversity" does not coincide with the ground reality when even after fifty years Babari Masjid, Godhara, and the terror strikes by Islamic fundamentalists, threaten to demolish 
the already fragile communal harmony between the Hindu and Muslim communities. It points to the fact that problems cannot be solved or peaceful existence assured simply by refusing to acknowledge them. To keep violence under the shadow of independence and nationhood, Indian official histories make certain strategic moves. First, though they take partition of India as historical event, great emphasis is given to the causes of partition and not to the violence that 'accompanied' it.

Accordingly, nationalist historians blame Muslim leaguers and the British for the bloody deeds of 1947. Ian Talbot, a British historian ascribes the cause of violence and partition to the so-called primitive, barbaric natives (Hindus, Sikhs and Muslim). In the similar way, Aysha Jalal, a Cambridge trained Pakistani historian, accuses Hindus, Sikhs and congress leaders for partition. And the Marxist historians give its credit to the socioeconomic forces of India- the developing antagonism between rich and the poor. (qtd. in Pandey, "Prose" 210). Whatever the cause and whoever the culprit, little emphasis is given to violence itself. Every care is taken to distance the general public from those fearful moments of the past by transforming the history of events into a history of causes. The actual acts of abduction, uprooting, train raids, trauma, madness, suicide, murder and other acts of destruction are rarely accorded the rightful place in history books. However, as Pandey believes, the causes behind partition and its political consequences only do not make the history of partition. Rather, it is also the representation of violence-the pains and cultural traumas, the abduction, migration, genocidal murders and the tales of rape-that constitutes partition.

Dominique Lapierre and Larry Collins outline intensity of the gruesome violence in graphic detail. And so, in a bewildering frenzy, Hindus, Sikhs, and Moslems turned on each other. India was ever a land of extravagant dimensions, and the horror of the Punjab's killings, the abundance of human anguish and suffering they would produce, did not fail that ancient tradition. Europe's people had slaughtered each other with bombs, shells and the calculated horrors of the gas chambers; the people of the Punjab set out to destroy themselves with bamboo staves, hockey-sticks, ice-peaks, knives, clubs, swords, hammers, bricks and clawing fingers. Theirs was a spontaneous, irrational slaughter. (359)

But Independence was partition and as Pandey suggests "partition was violence, a cataclysm, a world torn apart" (Remembering 5). Glorification of independence in the history, therefore, has to be accompanied by a detailed description of massive violence, inhuman cruelty and brutality. As any tale of civilization is equally a tale of barbarism, a balance should be maintained in the representation of independence, partition and violence. During the partition about a million people were butchered cold bloodedly simply because they happened to belong to another community. As Mushirul Hasan observes: An estimated 12.5 million people were displaced and uprooted. In the Punjab alone 12 million of Hindus, Muslim and Sikhs were involved in murder, 9 million of people started migration over night and until 1950s, 4000 Muslims a day boarded the train to Pakistan. Altogether 75,000 women were raped and abducted. (50-51)

Similarly, Lapaiere and Collins term the flow of humanity in the period as the greatest migration in history... with an enormity of anguish and suffering almost beyond human competence to imagine or the human sprit's capacity to endure. One of them alone represented 800,000 people, a caravan almost mind-numbing in dimension, the largest column of refugees Man's turbulent history had ever produced. (402) However, such acts of violence are rarely given the importance they deserve partly given the tinderbox of sectarian tension and largely because in the discourse of history violence suffered by the common people is little worthy of consideration since it is "senseless" and "irrational." What count are the cause and the political and constitutional settlements. Hence professional historiography offers a minimalist gesture toward the ordinary people and their struggle and tends to persist with the colonial mentality.

The number of people killed during the partition has never been established. Partition historiography that is claimed as scientific and objective however persists with a journalistic trend to cite the casualty figures although it is concerned with much greater figure. It almost invariably adopts a method of taking median or averaging. 
Estimates of the dead vary from 200,000 to two million. "Menon and Bhasin choose 500,000-1,000,000 ... Mohammad Waseem accepts a figure of 'about half a million' ... Wolpert settles for approximately one million" (qtd. in Remembering 89). There is no basis for accepting these figures which has become just a convenient way of figuring the death tolls. In what is professed as a comprehensive and objective book on partition and independence, Lapierre and Collins in their introduction to the aforementioned book adopt a disparaging casual tone as if the number of dead had little significance: No one, of course, will ever know how many people died in those awful weeks. Mountbatten preferred to use the figure 250,000 dead, an estimate undoubtedly tinged with some wishful thinking. Most historians of the period place the figure at half a million. Some put it as high as two million. (xvi)

The word "preferred" in the above quotation brings forth the frivolity with which historians and politicians treat the subject by downplaying its significance in relation to political and constitutional achievements. The problem in these discourses that give credibility to an average figure lies not so much with the numbers themselves but with the absolute certainty and objectivity they seek to assert in the guise of objective narrative. Gyanendra Pandey argues, "statistical truth is not the main point at issue. What is at stake is a grim political message, bolstered by an axiomatic history" (Remembering 81). Similarly, Patrick French explores the reasons behind the obliteration of violence: It was in the interests of the governments of Attle, Jihhan, and Nehru to play down the scale of the massacres, since they all bore a degree of responsibility .... Mutual genocide never attracts attention in the way that a one-way genocide does. So the terrible, squalid deaths in countless streets and fields were sidelined. (348)

Disciplinary historians refrain from noticing that independence of India went together with partition of it, which was surrounded, accompanied and constituted by massive violence. Even the widely and critically acclaimed writers of Freedom at Midnight fail to allot due representation to the enormity of violence and personal suffering except a few passing glances which could not be avoided or which were necessary to highlight the savagery and irrationality of the uncultured people who had revolted against their "civilized masters." Therefore, if national history of India has to become the history of Indian people, "it must represent their tales of suffering and the many sided struggle to liberate India" (Pandey, "Prose" 204). The history of communalism, sectarian strife and bloodshed must be represented in its fullness and not as an "inconsequential motif in the larger drama of India's struggle for independence" (206). Hence Gyanendra Pandey is right to assert that "the history of civilization is at the same time history of violence" (Memory9) and such violence must be articulated in its fullness, discussed and analyzed so that mankind can learn from the past and plan a better future.

Similarly, professional historians and fiction writers tend to reduce the significance of the violence by highlighting gestures of kindness and humanity amidst bloodlust and revenge. Alok Bhalla argues that, "The best of fiction writers are not concerned with merely telling stories of violence, but with making a profoundly troubled inquiry about the survival of our 'moral being' in the midst of horror" (qtd. in Remembering 62). Again Alam and Sharma emphasize the "gestures of kindness and protectiveness, for every instance of killing that we hear of, we also hear of somebody's attempt to help, to rescue, somebody giving a shoulder to lean" (61). Despite being grossly horrific, a note of casualness pervaded during the festival of death. Hasan Monto gives a chilling account of violence: "death became random: The knife slid down his groin. The pyjama cord was cut into two. His genitals were exposed. "Chi chi chi, I've made a mistake," the assassin said, with a sense of remorse" (qtd. in French 348).

What is questionable in traditional histories is not the authenticity of the gestures of kindness, for there were many and without them the scale of violence would have been certainly much higher, but the intention to disparage the intensity and horror of violence and to highlight its essential irrelevance compared to the political and constitutional achievements. Pandey argues for a full and complete enquiry into the underlying causes and effects of the partition violence on different communities. 
These facts must not be allowed to obscure the history of changing Hindu-Sikh-Muslim relations, of emerging right-wing formations and attitudes, of a state that has become increasingly partisan and, indeed of a growing societal tolerance of violence. They must not become an excuse for a retread into the tired nationalist proposition that 1947 (or 1984, or 1992) was an aberration, the handiwork of 'outsiders' and 'criminals'. (Remembering 64)

In fact to what extent partition as a constitutional and political arrangement changed the life of Indian and Pakistani people can be a subject of debate and discussion. But what it indeed did and did very successfully was to embitter the two communities by keeping them firmly set at each others throat. Also paid was the price far exceeding the price for freedom. It is therefore necessary to acknowledge and document the deaths, trauma, and suffering of the millions in the course of independence and partition as a token of justice to the victims that can also serve as a dire precedent for any future catastrophes.

\section{Discussions And AnalysiS: A Bend in The GAnges}

A Bend in the Ganges by Manohar Malgonar repudiates the claims of traditional historiography that independence of India was just a constitutional and political arrangement. It seeks to highlight the different motives of Hindus and Muslims in seeking the independence from the British rule. Indeed as Huntington suggests, "Of all the objective elements which define civilizations, however, the most important is usually the religion" (Huntington 42). By focusing on differences of cultures and world views between the two communities, the novel forwards the question whether it would be more desirable for them to live separately given the long history of uneasy relations. Indulging in what Fredric Jameson calls "the politics of blame," thereby blaming what had by now became an enemy nation, the novel is nonetheless significant for an analysis of the rise of religious nationalism that seeks to critique the secular formulations of Indian history. Also, the novel brings forth the drawbacks of Gandhian non-violence in the world where existence itself depends on the effective use of organized violence.

Manohar Malgonkar is best known as a writer of romance and adventure in such novels as Distant Drum (1960), Combat of Shadows (1962), The Princes (1970). However, his novel, A Bend in the Ganges (1964), is not only a well-crafted novel, but also an important work of fiction. In this complex and powerful novel, Malgonkar, himself a hunter and army colonel, considers aggression and violence in regard to Gandhi's doctrine of ahimsa or non-violence. The novel traces the destruction of two families and by extension of the two communities during the independence struggle and partition. Violence is central in the life of each central character and in the life of the nation.

The novel hovers around and concerns the change in perception of its central protagonists, namely Debi Dayal and Shafi Usman, amid the confusion and catastrophe before, during, and after the partition. Written in line with the ideology of Hindutva, it departs from the secular nationalism and adopts a religious view on nationalism. Although a continuity of nationalist rhetoric, the novel nevertheless attempts a critique of Gandhian doctrine of absolute non-violence and openly calls for the overall militarization of Hindu community and by extension of India. The novel moreover takes part in the politics of stigmatization where an individual or community that might have been received easily in ordinary social intercourse is readily othered and demonized thereby breaking the claim that his other attributes have on us (Goffman 205). In light of the deep bond that emerged between Hindus and Muslims in their common struggle for independence, the murderous bitterness during and after partition can be attributed to the stigmatization of differences. The communities those were mutually acceptable some time ago despite some differences suddenly became completely unacceptable due to the tribal stigma of race, religion and nation.

Following the call from Gandhi to boycott foreign goods, one of the central protagonists, Gian Talwar, in a fit of revolutionary idealism sets ablaze his English blazer so as to purify himself of foreignness. Although hesitant to dispose himself of so precious a commodity, the initial hesitation is overcome by the sheer pressure of the crowd that is hailing him: "He felt a sudden desire to turn back, but it was already too late" (A Bend in the 
Ganges 3$)^{1}$. Whatever his initial anxiety, he is very soon relieved; the fragile resolve quickly gets strengthened by the act of an attractive woman who herself hurls her fur coat into the fire. An almost mocking tone ever present in the narrative acts as a sharp rebuke to the Gandhian school of non-violence, the so-called path of the braves. This mockery of non-violence in its turn serves to highlight the revolutionary activities being waged on by the likes of Debi Dayal, Shafi Usman, and Basu, a conglomerate of Hindu, Sikh, and Muslims. They are also freedom fighters but unlike Gian they belong to a terrorist group, which firmly believes that non-violence is the philosophy of the sheep, and that Gandhi'snon-violence will emasculate the entire nation. This violent struggle is led by Hafiz Khan. But for Debi Dayal and other members of the Hanuman Club, Shafi Usman is their leader. The members of this group are young boys, both Hindus and Muslims. They are dedicated to the overthrow of British rule in India and to Hindu-Muslim unity. The group has carried out its activities undetected and has an impressive record of achievements. Shafi Usman is the most wanted man of the group and so he goes disguised as a Sikh. Debi is more or less the deputy leader of this group, next only to Shafi.

Debi and Shafi's initiations into this group have however stemmed not from a strictly political belief as such but due to the injustices of the British. Debi's initiation begins with his hatred for the British prompted by an attempted rape of his mother by a white soldier which also symbolizes the rape of the motherland by a foreigner. Within six years of this incident a "weedy, pampered, overdressed, a typical rich man's son" (63) grows to a first-rate judoist and a fearless terrorist. The child who pitifully depended on his sister, who was afraid of shadows in the dark, who did not have the courage to break up a white-ant hill, who had made a scene when Mr. Muller was going to drown a puppy, participates in burning a military plane, the sight of which brought him "the joy of secret fulfillment"(76). Similarly, Shafi Usman too has a personal cause for his hatred of the British. The shooting of his father, who was only an innocent spectator during the Jallianwala Bagh massacre and the insults suffered by him and his mother in crawling on their bellies while returning from his father's funeral, have embittered him against the rulers.

The desire for a united front is so strong that the group denounces religious affiliations and partakes of beef and pork strictly prohibited by their religions. However, the intimate bond among these religious communities is foregrounded simply to highlight the impending fall apart. The group for a long time has been working together taking up considerable risks and sabotaging the infrastructures so as to weaken the British war efforts. The cell comprising all religious groups has no faith whatsoever in Gandhian non-violent methods and is bent on driving British out of India through force. Shafi, an ardent revolutionary strongly rebukes Gian, a follower of Gandhi, and challenges him to find a single instance in history, of just one country which has been able to free itself without resorting to war. Singh alleges that "Gandhi is the enemy of India's national aspirations" (4). Gian however has no doubt whatsoever in Gandhian doctrine, "the philosophy of sheep, a creed for cowards" as alleged by Singh. Gian would simply not budge an inch in his faith: Ahimsha is the noblest of creeds. There can be nothing more sacred. No man has the right to raise his hand against another, whatever the provocation. I shall never do it. It takes greater courage; non-violence is not for the weak. (5)

In spite of this unequivocal reaffirmation, Gian's creed of non-violence is found to be wanting and turns out to be superficial when it meets a major test in the chapter titled "Home-Coming" which is both literal and metaphorical. In a curious turn of events, this strong believer is shaken to his bone by what the events that follow. A family rivalry turns bloody scene when Gian's brother Hari is killed by his own relative Vishnu-Datt. In a complete adherence to his own faith, he has simply become a passive witness to his brother's death which could have been averted had he taken some courage in physically saving his elder brother. But still, his faith is intact since the law of the land was there to punish this heinous act. But justice takes a long course and at last his faith crumbles with no justice at the hand of law. He forsakes his Gandhian self and avenges his brother's death and ends up in the cellular jail in the Andamans. The narrative preceding these events evokes the deadly image of Shiva, to depict the ambivalent character of life as personified in many Hindu gods and more importantly to show the religious justification of violence. Gian discerns a paradox in the image of Shiva .... The opposite 
qualities of the face and the pose troubled him: the face was calm, serene, lost in the enjoyment of the dance; the pose, caught up in the throes of anger, frozen in a particularly violent gesture of the death-dance.

Like the goddess Mahadevi, who besides being the loving mother is also Kali, the goddess of terror and death. Shiva is both the god of creation and annihilation. When sent to Andaman to serve his sentence, Gian helps the British officers and even manages to become an informer, which for revolutionary activists is symbolic of the complicity of non-violent movement in prolonging the occupation of India. Gian's lowliness and kowtowing is in sharp contrast to the proud self of Debi Dayal who never falters before the hostility of the British. He is also serving prison sentence for attacking a British military plane. In fact, Debi has been made to suffer unwittingly by Gian when he helps in recapture of Debi while he was trying to escape. This event helps to rescue Gian from his apparent liking of the British and by extension is directly aimed at those non-violent activists who are "begging" for independence rather than "fighting" for it. But the most significant of all events in the novel is the raid on Ram-Rahim Club that acts as a first in the chain of events of Muslim betrayal of national aspirations and their fierce communalism. As a group of nationalists, the ring operates quite detached from whatever is going inside the country in the name of religion. They even partake of beef and pork thereby dismissing their religious identities. However, the bond that has united them now is about to give in owing to the continual strife between the two communities. A host of historical events take its toll on Shafi, the ring leader, who looked at Debi-Dayal and once again felt that quick unreasoning pang of jealousy. He [Debi] reminded him of a more youthful Nehru; the theatrical good looks, the background of wealth and learning; the refinement of manner, the awareness of built-in-leadership. (75)

The allusions are undoubtedly to the history of invasion of India by the Mughals and the subsequent rise of Muslims in wealth and power vis-à-vis the Hindus. The jealousy is stirred by the fact that the former ruling class was no more in charge of the country; and was now reduced to the former condition of the Hindus. The writer having granted some praise and acclaim to the fight put up by the Muslims along with the Hindus against the common enemy as in the popular armed revolt of 1857 and subsequent, now makes a familiar move typical of Indian nationalists. Being reduced in power and number, the Muslims must now yield to their age-old tactics of secession. The hang-up of past superiority would not allow them to accept a second grade position, and in the democratic country, the sheer number of Hindus would not let them rise into the corridors of power. So the only viable alternative available to the inherently separatist Muslims is to demand another country of their own.

Yet again, the incident involving the betrayal of Debi Dayal and others by Shafi, delves into the age-old nationalist rhetoric about Muslim betrayal of India. The dialogue between Hafiz Khan and Shafi serves to highlight what has been thought of as the nature of Islam by other main religions. As a revolutionary, Shafi cannot bear the fact that he would stand against what he has until now been standing for, the concept of nationalism and HinduMuslim brotherhood. But still Shafi is ill at ease with the arguments put forward by Hafiz: "The enemies of the moment are not the British; they are the Hindus" (83). But in yet another maneuver reminiscent of politics of blame, effort is made to point the finger squarely at the Muslims for stirring up hatred and violence in their campaign for Pakistan, the genesis of it being the Direct-Action Day initiated by the Muslim League. Shafi, as a symbol of all nationalist Muslims, cannot be relied upon even if they do not vaunt their preference for Pakistan. At heart, they are all the same-betrayers. Having received information of imminent raid at the Hanuman Club, from another Muslim Hafiz, Shafi warns as many as he could and he should. And in the final crumbling of whatever faith there was, Shafi wakes to the fact that all he had warned were Moslems, not a single Hindu: "It was the sort of coincidence that worried him for a long time, but even to himself, he refused to admit that it had anything to do with the visit of Hafiz" (89). The pseudo-political ideals of patriotism simply cannot stand up against the rousing flame of communalism. For an avowed nationalist, Malgonkar, this act shows the inherently communal nature of Muslims where nationalism is supposed to be subservient to religion. Since territorial occupation alone cannot guarantee national loyalty. Communities that are unable to accept India as the source of their religion cannot make the Indian nation. Their religious commitments lie outside of their birth and ... makes their political commitment to Indian nationhood inherently dubious. (Puri 159) 
Muslims who view their religious commitments far more important than their national commitments hence stand at a crossroad since they cannot deny that religion comes before nation in Islam and as a land of their birth find it very hard to disclaim their loyalty toward their motherland. But all these statements are made not so bluntly since it would have legitimized the secession of Pakistan as there can be no reason to remain united with the people who consider you a perverse by your very religion of Islam. In fact, the ideology of Hindutva itself can be said to have tacitly approved the division of the country along communal lines since it saw India as a country with two nations. Along with the cultural chasm, Muslim scholars like Mumtaz Hasan see "the lack of any prospects of economic well-being among the Muslims in the face of the Hindu monopoly of the economy as major contributory factors in the demand for partition" (325). The novel however makes a careful attempt, although feebly, to strike a balance between two the communities-all was right with India except the demand for Pakistan.

As the course of events move on, Debi returns after six years in Andaman and things have become quite different on the ground. Hindu and Muslims are at each other's throat. Yet Debi as a nationalist is visibly agitated: "What a pass we have come to, fighting ourselves ... It is almost as though ... the British have succeeded in what they set out to do. Set the Hindus and Muslims at each other's throats" (283). But this seemingly secular nationalism is neutralized by a careful maneuver through Basu whose wife has been thoroughly disfigured by an acid bulb thrown at by, presumably the Muslim, who as Basu puts it had the "urge to seduce her" (284). The act of throwing acid here serves as a microcosm of what would be the eventual dismemberment of the country. The question of violence also becomes central here. Basu puts a rhetorical question "Would you remain non-violent if someone threw acid at the girl you loved? -Would Gandhi?"(285). The question of violence has become crucial to the existence itself. As the Muslims have taken violence as a means of achieving their aim, Hindus should also do the same only if to keep the country and the community (Hindu) intact. Violence now becomes a legitimate and even necessary means in face of growing Muslim hostility. For the Muslims, violence is a choice of preference whereas for the Hindus it is a compulsion so as to secure their larger interests-the need to keep the country united.

Moreover the right-wing Hindu views are justified not only through Hindus, but through Muslims also. The threat posed by the Muslims is present and real for the community which has been made a "nation of sheep." Basu firmly believes Gandhi has effectively wiped out the sense of courage and resistance from the Hindus: For every Hindu that had to die, five will die because of the way the doctrine of non-violence has caught on .... And what will Gandhi do? He will go on a fast, a fast perhaps unto death. But will he ever admit failure? No. What is the future for a country nurtured on non-violence in a world of mounting violence? How are we to survive? Can a non-violent nation have a violent army? (286) This apparent criticism of Gandhi directly emanates from what has now been labeled as Hindutva ideology that wants a strong army and a militant population ready to face every eventuality. Equating his own inability to protect his wife with the inability of his countrymen, Basu mocks at the concept of absolute non-violence which has left the country utterly helpless when the country itself has been ravaged by violence and its boundaries violated to create a nation for a religious community.

Malgonkar moreover justifies the right-wing Hindutva argument for the militarization of the country and people, not only through Hindus but also through Muslims. Shafi who had earlier if unconsciously betrayed the Hindus has now no doubt whatsoever about his deeds. In fact, he views it as a just act of revenge for the police atrocities in Bombay against Muslims. As if to give more credence to the right-wing Hindutva argument, Malgonkar sets Shafi squarely against the Hindus. Ruminating on the thought of impending civil war for the creation of Pakistan, Shafi remarks: But the Hindus were pacifists at heart, their leaders fond of extolling secularism ... were soft and shrank from bloodshed. They would not be match for the Muslims. (290) Secularism also is here made to look like the idea of Hindus who were "fond of extolling it" though Muslims had no faith whatsoever in that secularism. The inherent decency of Hindus is such that even after coming to know about the betrayal, Debi is in no mood to settle the score. In fact, much to our surprise, he is very much conciliatory. Amidst all the violence, 
Debi, an advocate of violence, now even wonders whether Gandhi was right: "It [the violence] almost makes one think that non-violence is perhaps the only answer" (284). However, his momentary belief too is short lived when Shafi thwarts his attempts at reconciliation when he informs police about Debi's whereabouts. The inherent meanness of Muslims is now at work. He wants to teach Shafi a lesson by buying his girlfriend not for his own purpose but just for hurting Shafi's pride. Shafi obviously cannot bear the insult and tries to disfigure the girl by throwing an acid bulb at her face. But Debi saves her by his heroic deeds. Although he has no plan or intention of keeping Mumtaz and even tells her to leave, the care of Mumtaz wins him over and they are finally married. Mumtaz curiously symbolizes those "good" Muslims who can still win over or have their place in India if they serve the "nation" well and prove their loyalty.

Hindus have no evil designs and what has endangered their peaceful coexistence is the idea of partition, the dismemberment of the country. Whatever the political intentions, the chapter "To Fold a Leaf" is squarely aimed at outlining the moral corruption of Muslims, their sensuality, and utter disrespect for women that overtly manifested itself during the wholesale rape of Hindu women. The idea of considerate and kind Hindu man is set against the background of inherently barbarous and lecherous Muslim men. However the inability of Shafi to buy his girlfriend gives credence to the Muslim accusation that the Muslims had become poor and marginalized since Shafi, like his Muslim brothers, has apparently no easy money to throw at women. Here the attempt at cultural smearing becomes a significant site for the analysis of disparity of economical and social powers between the two communities.

As the events move on and partition becomes a reality, the naked dance of violence comes into play. Tekchand, the father of Debi, who until yesterday was quite at ease, now feels the heat of the violence. Being a prosperous and powerful man, he is an obvious target for the Muslims. This powerful man is made to plead like a servant before a minor police officer highlighting the change in power structure instigated by communalism. As the climax approaches, Malgonkar makes a final preparation for distinguishing the two communities. Shafi, who has been utterly humiliated by Debi, sees a soft target to settle his score. Shafi's eyes however are firmly set on Sundari so as to defile Debi's family and by extension Hindu chastity and dignity. In an ensuing feud, Debi's mother is killed without being defiled. All the three escape on a car. Tekchand is left on the way, and Gian and Sundari presumably make an escape to Hindu majority province and live happily ever after. But the rub lies with Debi's ordeal. Debi now married to Mumtaz boards a train to come to his native land. His act in itself is an audacious one since belonging to another community was a ready death certificate. Despite his disguise, he is found out and killed despite his wife's plea to spare him. These events serve to highlight the cruelty of communal violence during partition.

The violence of partition affected Hindu, Muslim, and Sikh communities very deeply that would continue to live in the memory of people for a long time to come. All three communities were more or less equally responsible for the atrocities and many wondered what had motivated them for such atrocities against the communities with whom they were not long ago sharing their every day joys and grievances. Although the figures of death run in million, it was astonishing that the death figures were distributed more or less equally among all three communities which is to say that all communities were powerful enough to oppose attacks on them where they were in sizeable numbers. Although Muslims in India were far less numerically compared to the Hindus, they were able to defend themselves and were defended by the state which they had been accusing as being against their best interests.

Despite the bigotry and disparaging attitude of the state and the majority community as alleged by Gyanendra Pandey and Muslim scholars like Prof. Mushrilal Hasan, the Muslims of India can be said to have fared far better compared to the minorities in the neighbouring Muslim states of Pakistan and Bangladesh. Moreover Pandey a Marxist poststructuralist cites different problems given the hostility between India and Pakistan in his inability to obtain a visa for studying the treatment of minority. But it does not behoove a critic of his stature to overlook yet another state where Hindus continue to live as a second class citizen. And it is here where Malgonkar 
through his novel $A$ Bend in the Ganges asks whether there is something fundamentally wrong with the Muslim community's view on minority communities like Hindus. His view on the basically intolerant nature of Islam cannot be said to be unfounded since minority communities in Muslim majority states have never enjoyed same degree of security and freedom as enjoyed by Muslims where they are in minority. A Muslim intellectual writer, Taslima Nasrin, in her novel Lajja, as presented in A Bend in the Ganges moreover reflects this fact in the novel. Pandey's and Hasan's critique of Indian nationalism as surrounding around mainstream religion is valid to the extent that they have brilliantly depicted the predicament and insecurity of minority community. But their huge drawback lies in their refusal to see the fate of the other minority community of the subcontinent.

India as a secular state does not discriminate its population on the basis of religion since its constitution bars politics on the basis of religion. But though Islamic states have also constitutional provisions prohibiting discrimination on the basis of religion, caste, or language, they cannot be said to have guaranteed full rights to the minority since their very constitutions have proclaimed Islam as the basis of their constitution. Taslima Nasrin, a prominent critic of fundamentalism of any sort, provides a harrowing account of torture inflicted on the minority Hindu community in the aftermath of the demolition of Babri Masjid on 6 December 1992. Herself a devout Muslim, she was served with a fatwa for writing against Islam by the fundamentalists and hence her views on the treatment of minorities by the states of India, Pakistan, and Bangladesh can be seen as a balanced account of the injustices perpetrated on minority communities.

Unlike, Gyanendra Pandey who sees Indian state as being increasingly partisan toward majority religion, Nasrin considers India as a secular nation where Muslims are on the top political positions and many cultural icons come from Muslim communities. In the novel, Lajja, Nasrin compares the situations in India with that of Bangladesh. The words of two central characters, Sudhamoy and Suranjan who are both leftists and loathe sectarianism, reflect the writer's perception of the difference that lies in the clashes between two communities. The father tries to soothe his son's attempt at migrating to India in the face of all out attack against Hindus where his daughter herself has been abducted by the extremists. As a nationalist, he holds his loyalty and love of the country beyond any religious or cultural affiliations and considers those assaults, rather naively, as an aberration: "Riots break out in all countries. Aren't there riots in India? Aren't people dying there?" The answer by his son reflects Nasrin's attitude more clearly. If it were riots I'd understand, Baba. These aren't riots. It is simply a case of Muslims killing Hindus .... However much we call ourselves atheists, however much we call ourselves humanists, those people out there will call us Hindus .... Sooner or later all of us will be shoved under a bridge to die. (213) Unlike India where Muslims though being in minority could retaliate and sometimes even perpetrate those crimes, the minority communities in Bangladesh and Pakistan rarely dare to voice their discontent given the prejudice of the state towards religion other than Islam.

Moreover, the most disturbing of all is the concerted attempt by the respective Islamic governments to disenfranchise and alienate the minorities. For the purpose, Nasrin points out Bangladesh, a country that got its independence at the cost of three million lives, refused to identify itself on the basis of religion with Pakistan, and declared nationalism and secularism as its guiding principles, mysteriously altered its constitution thereby claiming Islam as its fundamental guiding principle much to the chagrin of the minorities like Hindus who had suffered and sacrificed no less for the struggle than the Muslims. "On 22 December 1982, Ershad declared that Islam and the principles of the Qur'an would be the basis for reframing the constitution" (192). The disparity in the treatment of the minority communities in different countries of the subcontinent can also be demonstrated on the basis of the ratio of population. It's a matter of common consent and knowledge that security and chances of employment contribute directly to either the increment or depletion of people. Although a work of fiction, Nasrin backs up her argument against extremism by statistics as well. The facts below alone demonstrate the miserable situation of minority religion in Bangladesh. In the last two decades more than half-a-million people belonging to minority communities have been forced to leave the country .... In 1941, the Muslims were 70.3 per cent of the population, while the Hindus were 28.3 per cent. In 1951, the Muslims were 76.9 per cent and 
the Hindus were 22.0 per cent. In 1961, the Muslims constituted 80.4 per cent, Hindus 18.5 per cent. In 1974, there were 85.4 per cent Muslims and 12.1 per cent Hindus. In 1991, the Muslims were 87.4 per cent, and the Hindus approximately 12.6 per cent. (189)

Given the more or less same level of literacy and social awareness in both communities, the continual eroding of the Hindu population can only be attributed to the lack of security and the persecution on the basis of religion. The insecurity felt by Hindus had in fact began soon after independence. When the war began, some ten million people had taken refuge in India of which eighty per cent were Hindus. And when they returned, most of them found their land and property had been confiscated. Many returned again to India, some stayed hoping that an independent country would give them social security. But their hopes were completely frustrated when the government only changed the names of the enemy property and refrained from delivering justice to the minorities.

Hence the general discussion of two works of fictions make clear that there is something wrong in the way religion is used for the purpose of gaining power in politics. Religion in the subcontinent still plays a vital role in the political spheres yet it has been generally found to be true that the states that take religious doctrine, as their guiding principles cannot be impartial to other religious communities as demonstrated by Nasrin's Lajja. Although subjected to some prejudices regarding their loyalty towards the state, the Muslim community in India fares far better than the minority communities in the Islamic states. The relatively disadvantageous condition of minorities in Islamic states can be attributed among social and political factors to the teachings of the Qur'an, which sees Islam as the only truth and believers in other religions as infidels.

Though rejected by moderate elements in Islam, the idea of Jihad, still exerts considerable influence among the fundamentalists who in turn use it to grab political power and dominance over other religion. It has an underlying idea that since Islam is a universal religion, force may be used to expand its borders and which ceases only when the unbelievers agree to accept the political authority of Islam (Hinnells 173). Hence Islam cannot be taken only as a religion in the traditional sense of the word since its stated objectives make explicit that its goals are more of political nature rather than strictly religious. However this is not to say that other world religions like Christianity have no political objectives since it had already waged a bloody war "the Crusade" against Islam in the Middle ages. The question however is about the methods used in achieving those goals and the degree of involvement of religion in politics in the modern world.

\section{CONCLUSION}

It can be concluded that religion in itself is not a scourge. Every people and communities have united themselves differently at different times may it be on the basis of religion, language, ethnicity, or nationalism. But in most cases religion has been the most salient feature of all. So the problem lies not in religion itself but in the effort by fanatic politicians and religious zealots in turning it as the basis of "hate politics" and perpetuating their hold on power. And also, it points to the fact that liberal democracy of the kind professed by the west has perhaps failed to deliver on its promises. Its blind sanctioning of ruthless and untrammeled capitalism has further antagonized the large masses of people who see it as a way for furthering the interest of some handful of wealthy and powerful people and nations. Modern political philosophies may have outlived their usefulness in the sense that they have not lived up to the expectation of material comfort and security. Unless a thorough revision is made of the shortcomings of the secular liberal democracy, religious extremism will continue to take the political space left vacant by the failure of secular politics. Politicians, policy makers, and above all the people who love their religion should stay vigilant regarding the rise in religious extremism of the kind that seeks to establish itself as the final truth and deny the existence of other religions. But religion that seeks to unite people and provide them with the meaning in life must be promoted to counter the selfish materialistic tendencies of capitalism and consumerism. Gandhi, despite some shortcomings, always fought for a just and non-violent society and was concerned with uplifting the humanity from its pathetic state. So, a frank and 
honest discussion of underlying problems - violence, rape, and murder, the question of uneasy existence of Muslims, and cultural prejudices - can only lead towards realizing the dream of "peaceful coexistence" and

"unity in diversity." The extreme dependence on other for ideas is never going to solve the problem since the problems faced by India are more or less unique to the troubled history of the subcontinent.

\section{REFERENCES}

1. Alam, Javeed, and Suresh Sharma. "Remembering Partition." Seminar 461 (1998): 98 -103.

2. French, Patrick. Liberty or Death: India's Journey to Independence and Division. London: Harper Collins, 1997.

3. Goffman, Erving. "Selections from Stigma." The Disability Studies Reader. Ed. Lennard J. Davis. New York: Routledge, 1997. 203-215.

4. Hasan, Mushirul. "Partition: The Human Cost." History Today 47.9 (September 1997): 47-53.

5. Hinnells, John R. ed. Dictionary of Religions. New York: Penguin,1984.

6. Huntington, Samuel P. The Clash of Civilizations and the Remaking of World Order. New Delhi: Penguin, 1996.

7. Lapierre, Dominique and Larry Collins. Freedom at Midnight. New Delhi: Vikas Publishing House, 1997.

8. Malgonkar, Manohar. A Bend in the Ganges. London: Hamish Hamilton, 1964. Nasrin, Taslima. Lajja. New Delhi: Penguin, 1994.

9. Niranjana, Tejaswini. Siting Translation: History, Post-Structuralism, and the Colonial Context. Hyderabad: Navya Printers, 1995.

10. Noorani, A. G. Savarkar and Hindutva. New Delhi: LeftWord Books, 2002.

11. Pandey, Gyanendra. "Can a Muslim Be an Indian?" Comparative Studies in Society and History. 41.4 (October 1999): 608-629.

12. Memory, History, and the Question of Violence: Reflections on the Reconstruction of Partition. Calcutta: K.P. Bagchi, 1999.

13. "The Prose of Otherness." Subaltern Studies VIII: Essays in Honour of Ranjit Guha. Eds. David Arnold and David Hardiman. New Delhi: OUP, 1994. 188-221.

14. Remembering Partition: Violence, Nationalism and History in India. Cambridge: CUP, 2001.

15. "Voices from the Edge: The Struggle to Write Subaltern Histories." Ethnos 60.3-4 (1995): 223-242.

16. Puri, Bindu. "Indian Nationalism and the Hindu Argument: Savarkar and Gandhi." Mahatma Gandhi and His Contemporaries. Ed. Bindu Puri. Shimla: Indian Institute of Advanced Study, 2001. 154-176.

Citation: Udaya Raj Paudel. "Communication of Violence, Religious Culture and Nationalism in A Bend in the Ganges". American Research Journal of History and Culture ; V4, I1; pp: 1-13

Copyright (c) 2018 Udaya Raj Paudel. This is an open access article distributed under the Creative Commons Attribution License, which permits unrestricted use, distribution, and reproduction in any medium, provided the original work is properly cited. 